Prepared in cooperation with the Legislative-Citizen Commission on Minnesota Resources

\title{
Streamflow Distribution Maps for the Cannon River Drainage Basin, Southeast Minnesota, and the St. Louis River Drainage Basin, Northeast Minnesota
}

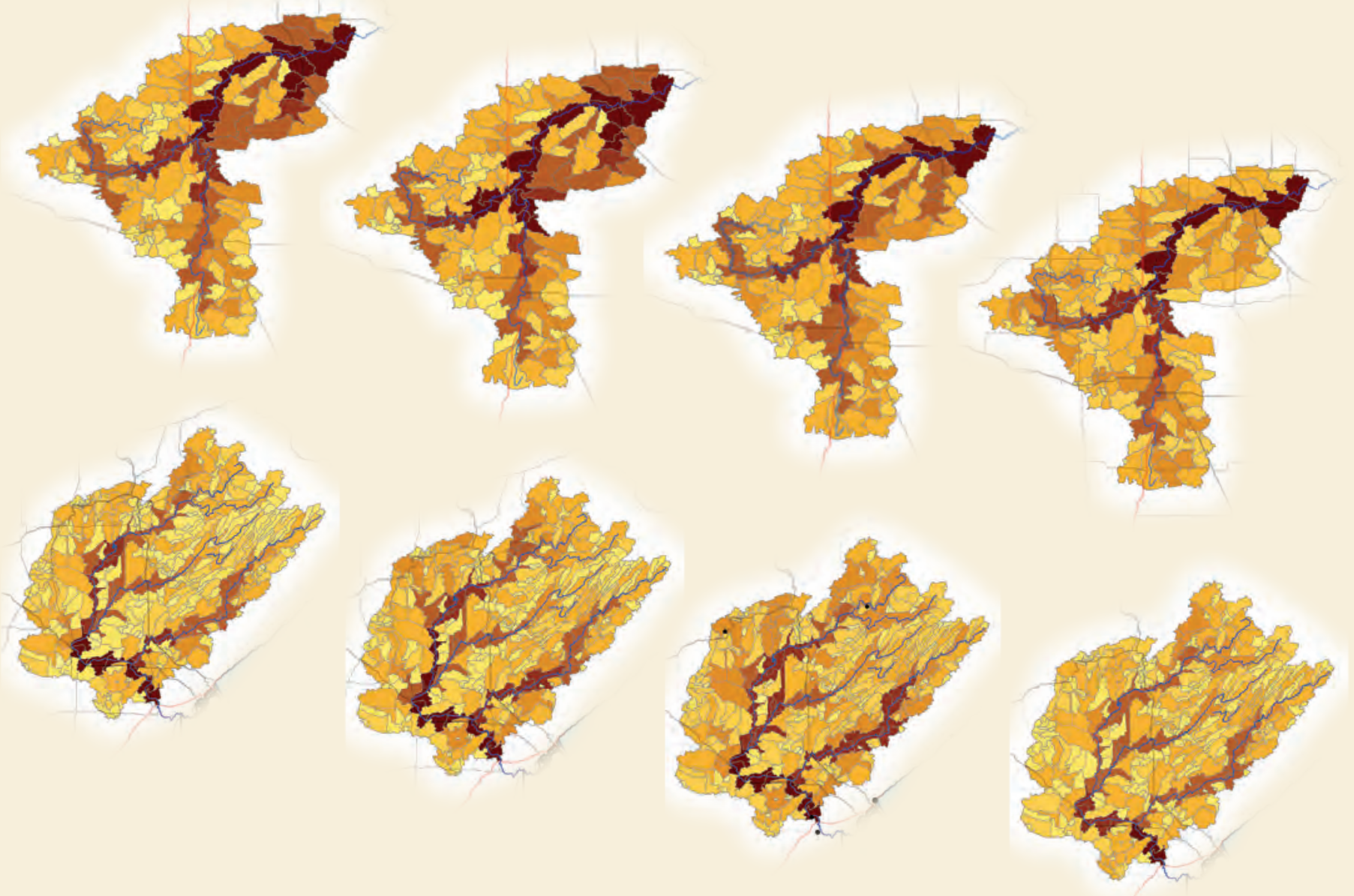

Pamphlet to accompany

Scientific Investigations Map 3390 
Cover. Streamflow distribution maps for the Cannon River and St. Louis River drainage basins. 


\section{Streamflow Distribution Maps for the Cannon River Drainage Basin, Southeast Minnesota, and the St. Louis River Drainage Basin, Northeast Minnesota}

By Erik A. Smith, Chris A. Sanocki, David L. Lorenz, and Katrin E. Jacobsen

Prepared in cooperation with the Legislative-Citizen Commission on Minnesota Resources

Scientific Investigations Map 3390 


\title{
U.S. Department of the Interior \\ RYAN K. ZINKE, Secretary
}

\section{U.S. Geological Survey \\ William H. Werkheiser, Deputy Director exercising the authority of the Director}

\author{
U.S. Geological Survey, Reston, Virginia: 2017
}

For more information on the USGS - the Federal source for science about the Earth, its natural and living resources, natural hazards, and the environment-visit https://www.usgs.gov or call 1-888-ASK-USGS.

For an overview of USGS information products, including maps, imagery, and publications,

visit https://store.usgs.gov.

Any use of trade, firm, or product names is for descriptive purposes only and does not imply endorsement by the U.S. Government.

Although this information product, for the most part, is in the public domain, it also may contain copyrighted materials as noted in the text. Permission to reproduce copyrighted items must be secured from the copyright owner.

Suggested citation:

Smith, E.A., Sanocki, C.A., Lorenz, D.L., and Jacobsen, K.E., 2017, Streamflow distribution maps for the Cannon River drainage basin, southeast Minnesota, and the St. Louis River drainage basin, northeast Minnesota: U.S. Geological Survey Scientific Investigations Map 3390, pamphlet 16 p., 2 sheets, https://doi.org/10.3133/sim3390.

ISSN 2329-132X (online) 


\section{Acknowledgments}

Funding for this study was provided by a grant from the Environmental and Natural Resource

Trust Fund of Minnesota (Legislative-Citizen Commission on Minnesota Resources) and from U.S. Geological Survey Cooperative Matching Funds.

Jeffrey Ziegeweid is acknowledged for generating the flow-duration curve statistics using the estFDC package. Sarah Levin and Robert Kay of the U.S. Geological Survey are greatly acknowledged for colleague reviews of the report. 



\section{Contents}

Acknowledgments ……...................................................................................................................

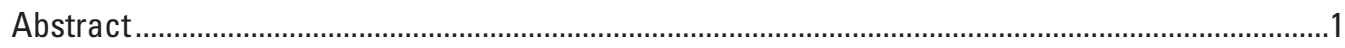

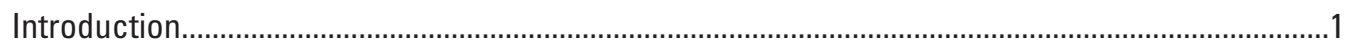

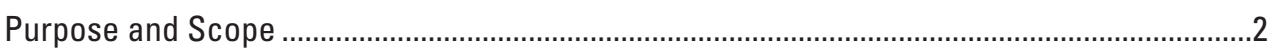

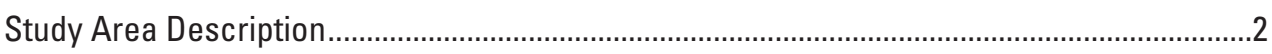

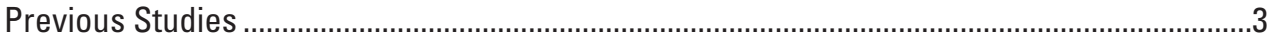

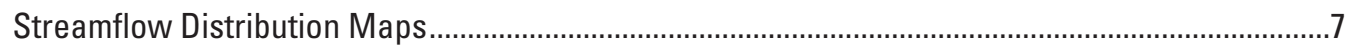

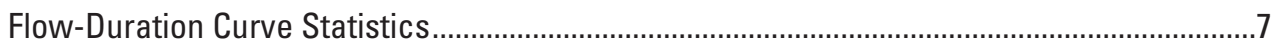

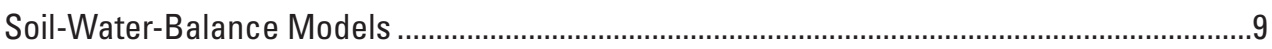

Cannon River Drainage Basin...................................................................................

St. Louis River Drainage Basin ......................................................................................11

Adjusting the Flow-Duration Curve Statistics using the Soil-Water-Balance

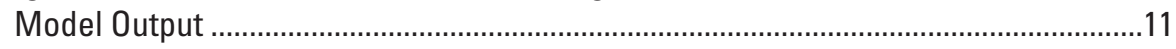

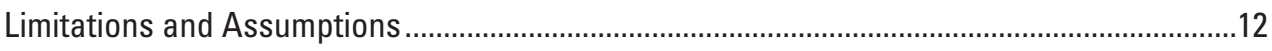

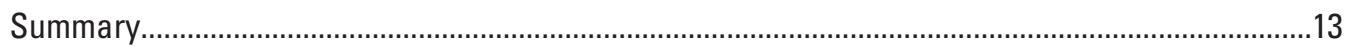

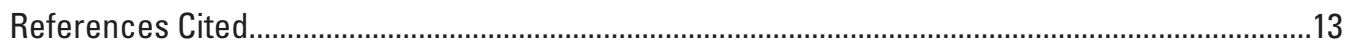

\section{Figures}

1. Map showing the Cannon River study area, including the entire drainage basin above the Cannon River at Welch, Minnesota, streamgage (U.S. Geological Survey station number 05355200), main stem of the Cannon River and the Straight River, major cities/towns, and other administrative boundaries

2. Map showing the six Minnesota groundwater provinces, as outlined by the Minnesota Department of Natural Resources (2017), along with the Cannon River drainage basin (above the Cannon River at Welch, Minnesota, streamgage [U.S. Geological Survey station number 05355200]) and the St. Louis River drainage basin (above the St. Louis River at Scanlon, Minnesota, streamgage [U.S. Geological Survey station number 04024000]).

3. Map showing the St. Louis River study area, including the entire drainage basin above the St. Louis River at Scanlon, Minnesota, streamgage (U.S. Geological Survey station number 04024000), main stem of the St. Louis River, the Whiteface River, and the Cloquet River, major cities/towns, and other administrative boundaries.

4. Map showing the five hydrologic regions in Minnesota, as defined by the regional regression equations from Ziegeweid and others (2015), along with the Cannon River drainage basin (above the Cannon River at Welch, Minnesota [U.S. Geological Survey station number 05355200]), and the St. Louis River drainage basin (above the St. Louis River at Scanlon, Minnesota [U.S. Geological Survey station number 04024000]).. 


\section{Tables}

1. Site information for the U.S. Geological Survey streamgages used for this study in the Cannon River and St. Louis River drainage basins, Minnesota

2. Annual mean base flow estimates rates (from 1996 to 2010) using three hydrograph separation techniques for the Cannon River at Welch, Minnesota (U.S. Geological Survey station number 05355200), used in model calibration analysis in comparison to the Soil-Water-Balance model estimated annual potential recharge rates.

3. Annual mean base flow estimates rates (from 1996 to 2010) using three hydrograph separation techniques for the St. Louis River at Scanlon, Minnesota (U.S. Geological Survey station number 04024000), used in model calibration analysis for comparison to the Soil-Water-Balance model estimated annual potential recharge rates.

\section{Conversion Factors}

International System of Units to U.S. customary units

\begin{tabular}{lcl}
\hline \multicolumn{1}{c}{ Multiply } & By & To obtain \\
\hline meter $(\mathrm{m})$ & Length & foot $(\mathrm{ft})$ \\
meters per kilometer $(\mathrm{m} / \mathrm{km})$ & 3.281 & foot per mile $(\mathrm{ft} / \mathrm{mi})$ \\
kilometer $(\mathrm{km})$ & 5.28 & mile $(\mathrm{mi})$ \\
millimeter $(\mathrm{mm})$ & 0.6215 & inch $(\mathrm{in})$ \\
\hline & 25.4 & \\
\hline square meter $\left(\mathrm{m}^{2}\right)$ & Area & square foot $\left(\mathrm{ft}^{2}\right)$ \\
square kilometer $\left(\mathrm{km}^{2}\right)$ & 10.76 & square mile $\left(\mathrm{mi}^{2}\right)$ \\
\hline & 0.3861 & \\
\hline cubic meter $\left(\mathrm{m}^{3}\right)$ & Volume & cubic foot $\left(\mathrm{ft}^{3}\right)$ \\
\hline & 35.31 & \\
\hline cubic meter per second $\left(\mathrm{m}^{3} / \mathrm{s}\right)$ & Flow rate & cubic foot per second $\left(\mathrm{ft}^{3} / \mathrm{s}\right)$ \\
millimeters per year $(\mathrm{mm} / \mathrm{yr})$ & 35.31 & inches per year $\left(\mathrm{in} / \mathrm{yr}^{2}\right)$ \\
\hline
\end{tabular}

Vertical coordinate information is referenced to the North American Vertical Datum of 1988 (NAVD 88), unless otherwise indicated.

Horizontal coordinate information is referenced to the North American Datum of 1983 (NAD 83). 


\section{Abbreviations}

$\begin{array}{ll}< & \text { less than } \\ \text { ET } & \text { evapotranspiration } \\ \text { FDC } & \text { flow-duration curve } \\ \text { HSPF } & \text { Hydrologic Simulation Program-FORTRAN } \\ \text { LUC } & \text { land-use classification } \\ \text { Minn. } & \text { Minnesota } \\ \text { NLCD } & \text { National Land Cover Database } \\ \text { SSURGO } & \text { Soil Survey Geographic [database] } \\ \text { STATSGO } & \text { State Soil Geographic [database] } \\ \text { SWB } & \text { Soil Water Balance [model] } \\ \text { USGS } & \text { U.S. Geological Survey } \\ \text { WRAPS } & \text { watershed restoration and protection strategies }\end{array}$





\title{
Streamflow Distribution Maps for the Cannon River Drainage Basin, Southeast Minnesota, and the St. Louis River Drainage Basin, Northeast Minnesota
}

\author{
By Erik A. Smith, Chris A. Sanocki, David L. Lorenz, and Katrin E. Jacobsen
}

\section{Abstract}

Streamflow distribution maps for the Cannon River and St. Louis River drainage basins were developed by the U.S. Geological Survey, in cooperation with the Legislative-Citizen Commission on Minnesota Resources, to illustrate relative and cumulative streamflow distributions. The Cannon River was selected to provide baseline data to assess the effects of potential surficial sand mining, and the St. Louis River was selected to determine the effects of ongoing Mesabi Iron Range mining. Each drainage basin (Cannon, St. Louis) was subdivided into nested drainage basins: the Cannon River was subdivided into 152 nested drainage basins, and the St. Louis River was subdivided into 353 nested drainage basins. For each smaller drainage basin, the estimated volumes of groundwater discharge (as base flow) and surface runoff flowing into all surface-water features were displayed under the following conditions: (1) extreme low-flow conditions, comparable to an exceedance-probability quantile of 0.95 ; (2) low-flow conditions, comparable to an exceedanceprobability quantile of 0.90 ; (3) a median condition, comparable to an exceedance-probability quantile of 0.50 ; and (4) a high-flow condition, comparable to an exceedance-probability quantile of 0.02 .

Streamflow distribution maps were developed using flow-duration curve exceedance-probability quantiles in conjunction with Soil-Water-Balance model outputs; both the flow-duration curve and Soil-Water-Balance models were built upon previously published U.S. Geological Survey reports. The selected streamflow distribution maps provide a proactive water management tool for State cooperators by illustrating flow rates during a range of hydraulic conditions. Furthermore, after the nested drainage basins are highlighted in terms of surface-water flows, the streamflows can be evaluated in the context of meeting specific ecological flows under different flow regimes and potentially assist with decisions regarding groundwater and surface-water appropriations. Presented streamflow distribution maps are foundational work intended to support the development of additional streamflow distribution maps that include statistical constraints on the selected flow conditions.

\section{Introduction}

Water resource management in a drainage basin requires knowledge of the water budget. The water budget states that the rate of change of water volume in a drainage basin is balanced by the flow in and out of all the surface water bodies (for example, lakes, streams, reservoirs, and wetlands) and underlying groundwater that make up the drainage basin (Healy and others, 2007). In Minnesota, the County Geologic Atlas program provides basic information on surficial and buried aquifers, including maps that detail the distribution and the lithologic and hydrogeologic properties of rock and sediments that lie below the land surface (Setterholm, 2014); this information can help estimate the volume of groundwater in storage within a particular geological unit. For streams and rivers with active streamgage networks, the volume and rate of surface-water flows at a streamgaged location are well quantified. For surficial aquifers, the volume and rate of groundwater flow in and out of surface water bodies are affected by the amount of surface-water flow and flow to and from deeper aquifers (Winter and others, 1998).

Water budgets provide a means for evaluating water availability and sustainability in the absence of robust groundwater modeling to determine sustainable groundwater yields within a basin or long-term monitoring of streamflow to determine continuous surface-water flows. These water budgets can be an important initial step for determining the water balance; however, predevelopment water budgets should not be used as the sole source of information for determining the amount of groundwater withdrawal that can happen in a watershed or to preserve minimum ecological streamflows (Bredehoeft, 1997).

The initial water budget generally requires accurate estimates of the spatial and temporal distribution of the water budget components, including potential recharge, surface runoff, evapotranspiration (ET), inflow from surface-water bodies and groundwater, and outflow from surface-water bodies and groundwater. The Soil-Water-Balance (SWB) model was developed to estimate the volume of potential recharge using widely available geographic information system datasets (Westenbroek and others, 2010) and includes estimates of ET and surface runoff. The SWB modeling assumes most 
potential recharge eventually flows into nearby surface-water systems as base flow. Combined with surface runoff, this analysis can be the first step for a water budget.

Another common problem with developing water budgets is that streamgages are not available to compute streamflow at every stream location; however, methods have been developed to estimate flow-duration curve (FDC) statistics at stream locations in Minnesota (Ziegeweid and others, 2015) with little or no long-term monitoring data, such as the upper reaches of large drainage basins. An FDC is a cumulative frequency curve that shows the fraction of time that specified streamflow is equaled or exceeded (Searcy, 1959). An FDC is built by sorting streamflow observed during a given period by magnitude and calculating the probability that a specified streamflow value will be equaled or exceeded. The fraction of time that the streamflow is calculated to have been equaled or exceeded is termed exceedance probability. At an ungaged location, the FDC is constructed from regression-based estimates of streamflow for 13 exceedance probabilities $(0.9999,0.999,0.99$, $0.95,0.9,0.75,0.5,0.25,0.1,0.05,0.02,0.001$, and 0.0001 ) that cover the range of streamflow (Lorenz and Ziegeweid, 2016). The FDC statistics define exceedance probabilities, and they are not a substitute for calculating continuous streamflow; instead, the FDC can provide a mechanism to assess water availability and determine initial estimates for sustained flow requirements (Unthank and others, 2012).

The contribution of base flow to total streamflow can be calculated for lower flow conditions, such as droughts, by integrating the SWB water budget components and the FDC exceedance probabilities. Additionally, the combined contribution of base flow and surface runoff at higher flow conditions, such as floods, can be estimated with this approach. To help guide the efforts made by the State of Minnesota to define water use sustainability from surficial aquifers and effectively manage streamflow during low-flow conditions, the U.S. Geological Survey (USGS), in cooperation with the LegislativeCitizen Commission on Minnesota Resources, combined SWB and FDC components to create a series of streamflow distribution maps for two pilot drainage basins. The selected streamflow distribution maps represent the relative contribution of base flow and surface runoff to total volume of streamflow for typical conditions, not necessarily the contribution for any particular time. These maps will help guide potential State cooperators such as the Minnesota Department of Natural Resources and the Minnesota Pollution Control Agency for proactive water management, ensure streamflows meet ecological needs at different flow conditions, and assist with decisions for groundwater appropriations at low-flow conditions.

\section{Purpose and Scope}

The purpose of this report is to describe the development of a series of estimated streamflow distribution maps at selected low-flow conditions and one high-flow condition for the Cannon River and St. Louis River drainage basins in Minnesota. The scope of the streamflow distribution maps was limited to the entire drainage basin above the farthest downstream continuous USGS streamgage. For the Cannon River, the maps included the entire drainage basin above the Cannon River at Welch, Minnesota (USGS station number 05355200). For the St. Louis River, the maps included the entire drainage basin above the St. Louis River at Scanlon, Minn. (USGS station number 04024000). Tasks specific to the estimated streamflow distribution maps were (1) analyzing the flow data collected at both gages (table 1); (2) generating FDC statistics for 505 smaller drainage basins within the 2 larger drainage basins using the Minnesota regional regression equations (Ziegeweid and others, 2015); (3) constructing and calibrating SWB models for each drainage basin for the period of January 1, 1996, through December 31,2010, primarily based on the published Minnesota statewide Soil-Water-Balance model (Smith and Westenbroek, 2015); (4) adjusting the FDC statistics based on the results of the SWB models; and (5) producing estimated streamflow distribution maps based on selected flow conditions representative of approximately median, low flow, extreme low flow, and high flow conditions.

\section{Study Area Description}

The Cannon River drainage basin in southeastern Minnesota consists of the Cannon River and the Straight River (Wotzka and Watkins, 2016). The drainage basin above the Cannon River at Welch, Minn., streamgage is 3,471 square

Table 1. Site information for the U.S. Geological Survey streamgages used for this study in the Cannon River and St. Louis River drainage basins, Minnesota.

[See figure 1 for station location; USGS, U.S. Geological Survey; Minn., Minnesota; fts/s, cubic foot per second]

\begin{tabular}{|c|c|c|c|c|c|c|}
\hline \multirow[b]{2}{*}{ Station name } & \multirow{2}{*}{$\begin{array}{l}\text { USGS } \\
\text { station } \\
\text { number }\end{array}$} & \multirow{2}{*}{$\begin{array}{l}\text { Drainage area } \\
\text { (square miles) }\end{array}$} & Latitude & Longitude & \multirow[b]{2}{*}{ Continuous period of record } & \multirow{2}{*}{$\begin{array}{l}\text { Maximum recorded } \\
\text { streamflow at } \\
\text { streamgage and date }\end{array}$} \\
\hline & & & \multicolumn{2}{|c|}{ (degrees, minutes, seconds) } & & \\
\hline $\begin{array}{l}\text { Cannon River at } \\
\text { Welch, Minn. }\end{array}$ & 05355200 & 1,340 & $44^{\circ} 33^{\prime} 50^{\prime \prime}$ & $92^{\circ} 43^{\prime} 55^{\prime \prime}$ & 1931 to current year (2017) & $\begin{array}{l}36,100 \mathrm{ft}^{3} / \mathrm{s} \\
\quad \text { April 8, } 1965\end{array}$ \\
\hline $\begin{array}{l}\text { St. Louis River at } \\
\text { Scanlon, Minn. }\end{array}$ & 04024000 & 3,430 & $46^{\circ} 42^{\prime} 12^{\prime \prime}$ & $92^{\circ} 25^{\prime} 07^{\prime \prime}$ & 1908 to current year (2017) & $\begin{array}{l}45,300 \mathrm{ft}^{3} / \mathrm{s} \\
\text { June } 21,2012\end{array}$ \\
\hline
\end{tabular}


kilometers $\left(\mathrm{km}^{2}\right)\left(1,340\right.$ square miles $\left.\left[\mathrm{mi}^{2}\right]\right)$ (U.S. Geological Survey, 2017). The Cannon River flows northeast towards the Mississippi River near Red Wing, Minn., and the Straight River joins the Cannon River in Faribault, Minn. (fig. 1; table 1). The Cannon River drainage basin covers parts of nine counties (fig. 1), including Blue Earth, Dakota, Freeborn, Goodhue, LeSueur, Rice, Scott, Steele, and Waseca.

The Cannon River drainage basin overlies two groundwater provinces (Minnesota Department of Natural Resources, 2017; fig. 2): the south-central province (groundwater province 2) and the southeastern province (groundwater province 3). The upstream sections of both the Cannon River and the Straight River are underlain by the south-central province, a glacial drift dominated landscape classified as thick clayey till overlying Paleozoic sandstone, limestone, and dolostone aquifers (Minnesota Department of Natural Resources, 2017). The glacial drift has a strong effect on infiltration and runoff, and the infiltration pathways are more diffuse through intermittent sand and gravel bodies, whereas the fine-grained units in this area impede infiltration (Runkel and others, 2014). Discharge to surface waters in the upstream part of the drainage basin follows a more diffuse network of preferential groundwater flow pathways (Runkel and others, 2014).

The more downstream parts of the Cannon River, in addition to the lower parts of the Straight River near the confluence of the two rivers, are underlain by the southeastern province. The southeastern province is an area with thin clayey till overlying Paleozoic bedrock and has karst characteristics, particularly in the eastern section of the drainage basin (Runkel and others, 2014; Minnesota Department of Natural Resources, 2017). The downstream parts of the Cannon River have a more pronounced connection to limestone and dolostone aquifers, in particular the Prairie du Chien Group (Groten and Alexander, 2013). High-purity sands within the St. Peter Sandstone exist in a substantial proportion of the Cannon River drainage basin (not shown). These high-purity sands are often extracted for use in hydraulic fracturing.

The St. Louis River drainage basin is one of the largest in northern Minnesota (fig. 2; Anderson and others, 2013). The drainage basin above the St. Louis River at Scanlon, Minn., streamgage is $8,884 \mathrm{~km}^{2}\left(3,430 \mathrm{mi}^{2}\right)$ (U.S. Geological Survey, 2017). The St. Louis River flows for 323 kilometers (km) (201 miles [mi]) towards Lake Superior before discharging into Lake Superior at Duluth, Minn. (fig. 3; table 1). The last $24 \mathrm{~km}$ (15 mi) of the St. Louis River comprise the St. Louis River estuary. Several tributaries join the St. Louis River along its reach, including the Embarrass River (not shown), Whiteface River, Floodwood River (not shown), and the Cloquet River (fig. 3) (Lindholm and others, 1979). The St. Louis River drainage basin covers parts of five counties (fig. 3), including Aitkin, Carlton, Itasca, Lake, and St. Louis; however, most of the basin is contained within St. Louis County.

The St. Louis River drainage basin overlies the central groundwater province (groundwater province 4) and the arrowhead province (groundwater province 6; fig. 2). The upstream part of the St. Louis River drainage basin is underlain by the arrowhead province, which is made up of Precambrian rocks exposed at the surface or covered by less than 9.2 meters (30 feet) of glacial till (Minnesota Department of Natural Resources, 2017). Groundwater in this region typically flows through faults and fractures within the Precambrian bedrock, although sand and sandstone aquifers are present in small areas. The lower parts of the St. Louis River drainage basin are underlain by the central province. The central province is an area with sand aquifers and thicker sand and clay glacial drift overlying the Precambrian and Cretaceous bedrock. Both the sand deposits within the glacial till and the bedrock deposits function as aquifers (Minnesota Department of Natural Resources, 2017). St. Louis River gradients are highly variable, ranging from 0.1 to 6.5 meters per kilometer (Lindgren and others, 2006). Much of the upper and middle sections of the St. Louis River drainage include shallow gradients, resulting in a highly fragmented stream network made up of small, short tributaries (Lindgren and others, 2006). In the lower reaches, gradients increase to near 6.5 meters per kilometer, particularly in a $24-\mathrm{km}(15-\mathrm{mi})$ reach below Cloquet, Minn. (fig. 3) (Lindholm and others, 1979).

The St. Louis River estuary, the final $24 \mathrm{~km}$ (15 mi) of the St. Louis River, has been listed as an Area of Concern by the International Joint Commission (Lindgren and others, 2006) because of the effects of heavy industry (for example, mining) and untreated urban effluent since the 19th century. Mining activity has happened within the St. Louis River drainage basin in the past 150 years. The Mesabi Iron Range (not shown), noted for rich deposits of iron ore, parallels much of the northern drainage basin boundary (Lindholm and others, 1979). Ongoing (2017) and potential future expansion of iron ore mining along the Mesabi Iron Range has been noted as an area of study and concern within the St. Louis River drainage basin (Fletcher and Christin, 2015).

\section{Previous Studies}

Several water-resource reports that include parts of the Cannon River drainage basin have been published during the last 45 years. A preliminary water budget that accounted for precipitation, ET, runoff, and a general compilation of water usage was included as part of a characterization of the Cannon River surface-water and groundwater resources by Anderson and others (1974). The high-purity silica sand deposits from the Middle Ordovician age were mapped across several midwestern states, including the Cannon River drainage basin in southeastern Minnesota by Ketner (1979). More recently, a comprehensive regional analysis of geologic controls on nitrate concentrations, in the context of the hydrogeologic attributes of surficial and bedrock deposits, was completed by Runkel and others (2014). Synoptic dye traces in a Cannon River tributary, Trout Brook, concluded that 30 to 40 percent of all Trout Brook streamflow was spring fed (Groten and Alexander, 2013). As part of the statewide watershed restoration and protection strategies (WRAPS) process, a Hydrologic 


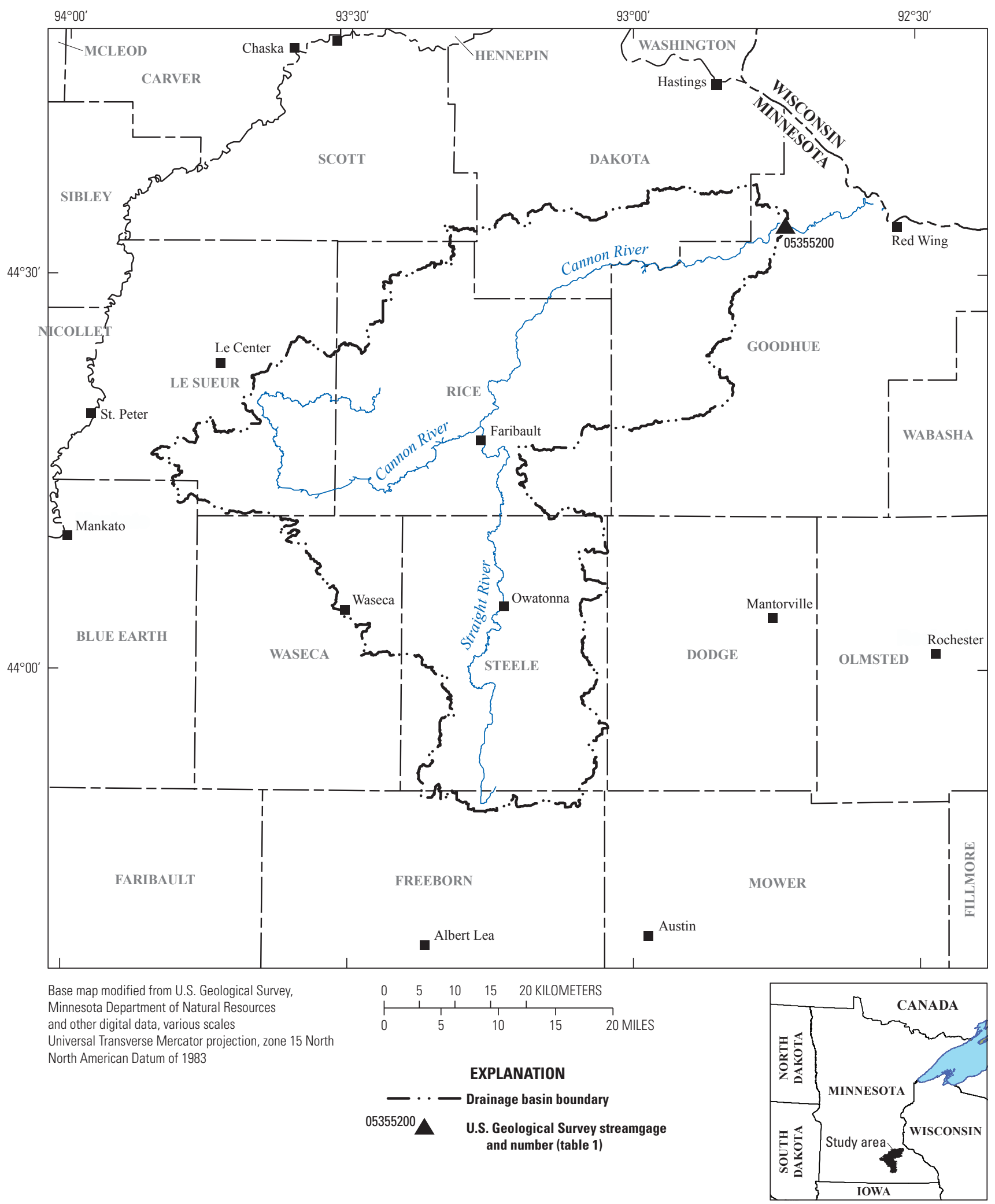

Figure 1. The Cannon River study area, including the entire drainage basin above the Cannon River at Welch, Minnesota, streamgage (U.S. Geological Survey station number 05355200), main stem of the Cannon River and the Straight River, major cities/towns, and other administrative boundaries. 


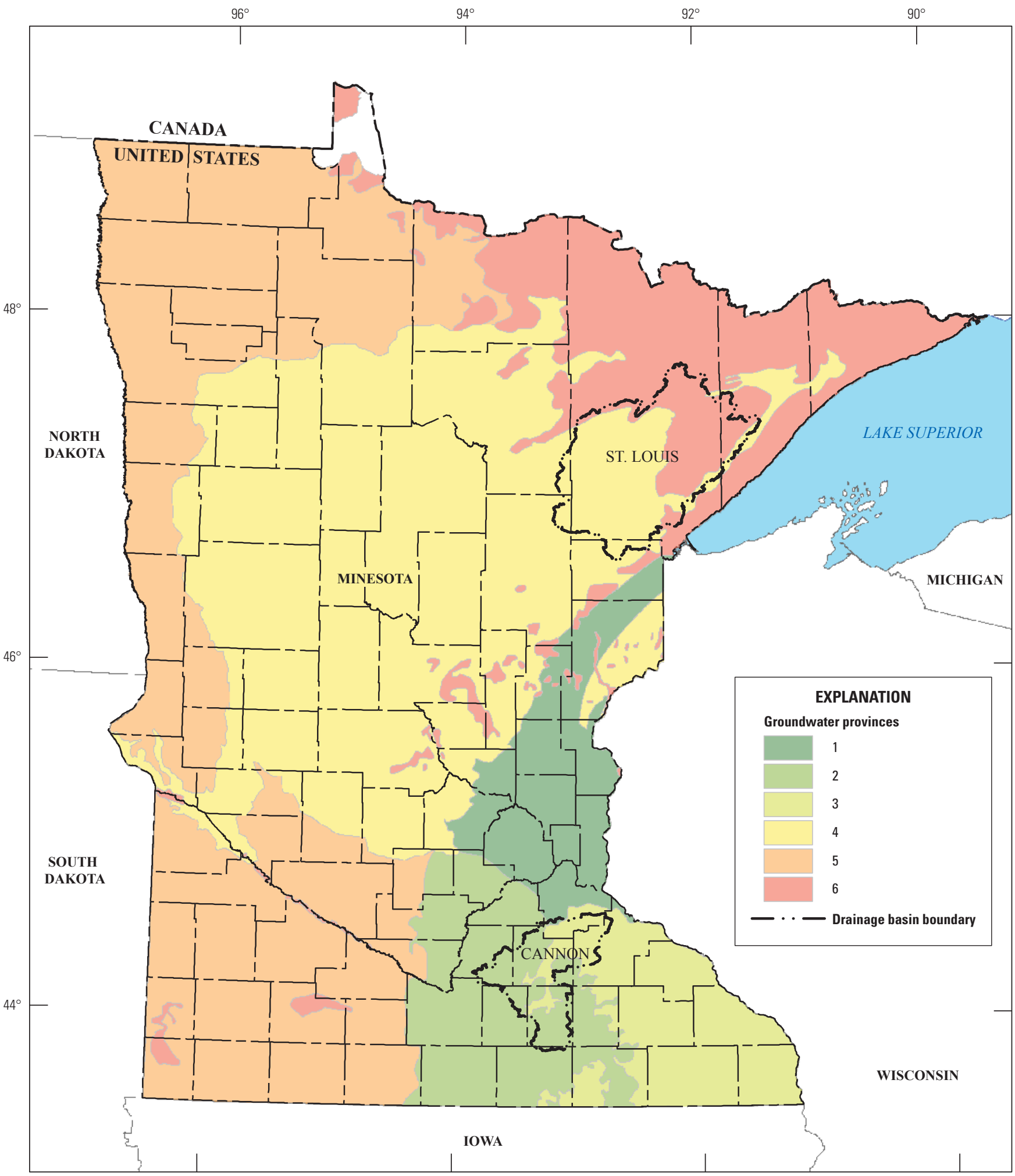

Base map modified from U.S. Geological Survey, Minnesota Department of Natural Resources and other digital data, various scales

Univeral Transverse Mercator projection, zone 15 North

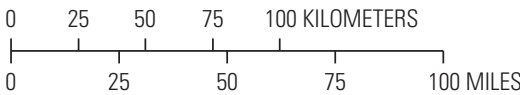

North American Datum of 1983

Figure 2. The six Minnesota groundwater provinces, as outlined by the Minnesota Department of Natural Resources (2017), along with the Cannon River drainage basin (above the Cannon River at Welch, Minnesota, streamgage [U.S. Geological Survey station number 05355200]) and the St. Louis River drainage basin (above the St. Louis River at Scanlon, Minnesota, streamgage [U.S. Geological Survey station number 04024000]). 


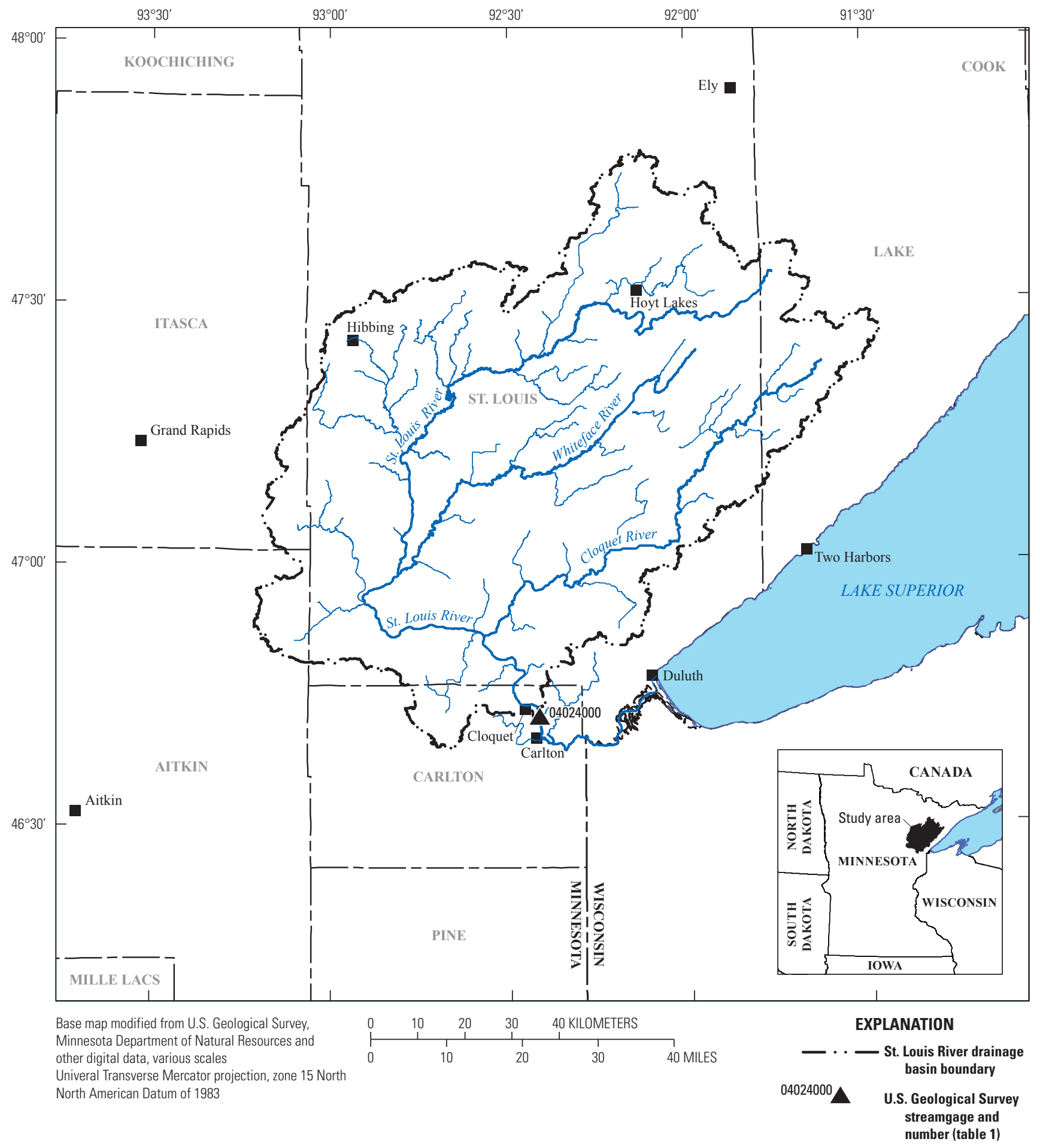

Figure 3. The St. Louis River study area, including the entire drainage basin above the St. Louis River at Scanlon, Minnesota, streamgage (U.S. Geological Survey station number 04024000), main stem of the St. Louis River, the Whiteface River, and the Cloquet River, major cities/towns, and other administrative boundaries. 
Simulation Program-FORTRAN (HSPF) model that simulated drainage basin hydrology and water quality was constructed, calibrated, and validated by LimnoTech (2015) for the Cannon River WRAPS (Wotzka and Watkins, 2016).

The St. Louis River drainage basin also has had several reports published in the last 4 decades. Similar to the Cannon River, a preliminary water budget was included as part of a characterization of the St. Louis River surface-water and groundwater resources by Lindholm and others (1979). Additionally, the Fond du Lac Indian Reservation water resources were characterized by Ruhl (1989). The physical characteristics and comprehensive water quality synopses for the St. Louis River were summarized by Lindgren and others (2006); similar to the Lindgren and others (2006) report, a separate Minnesota Pollution Control Agency-led summary monitoring and assessment report was published by Anderson and others (2013). After the severe flooding of the St. Louis River in 2012, Czuba and others (2012) characterized the high-water marks for several communities in and around the St. Louis River, also creating flood-peak inundation maps and water-surface profiles for several of the most affected communities. Similar to the Cannon River, an HSPF model that simulated drainage basin hydrology and water quality was constructed, calibrated, and validated by Tetra Tech (2016).

\section{Streamflow Distribution Maps}

Methods used generally are cited from previously published reports (Smith and Westenbroek, 2015; Ziegeweid and others, 2015; Lorenz and others, 2016). The SWB model developed for Minnesota at a 1-km² resolution (Smith and Westenbroek, 2015) was used as a baseline model for the Cannon River and St. Louis River SWB models. Regression equations developed in Ziegeweid and others (2015) were used to estimate the FDC quantiles, based on hydrologic regions developed in Lorenz and Ziegeweid (2016). If techniques varied substantially from previously documented methods because of available data, model domain resolution, or time periods, those techniques are described in detail in this report. Estimated streamflow distribution maps were produced for four flow conditions as referenced to the long-term discharge characteristics for the streamgages on the Cannon River at Welch, Minn. (USGS station number 05355200), and the St. Louis River at Scanlon, Minn. (USGS station number 04024000). These profiles covered the following flow conditions: (1) extreme low-flow conditions, comparable to an exceedance-probability quantile of 0.95 ; (2) low-flow conditions, comparable to an exceedance-probability quantile of 0.90 ; (3) median flow, comparable to an exceedance-probability quantile of 0.50 ; and (4) a high-flow condition, comparable to an exceedance-probability quantile of 0.02 .
The FDC statistics were generated using the estFDC method, part of the DVstats package (Lorenz, 2016) for the R statistical environment (RStudio Team, 2016). The estFDC method estimates streamflow at selected exceedance probabilities for ungaged sites in Minnesota, based on the regression equations developed from Ziegeweid and others (2015). The SWB model executable used for this study was compiled by Steve Westenbroek of the USGS on June 8, 2015; the SWB lookup table was based on the published Minnesota statewide Soil-Water-Balance model (Smith and Westenbroek, 2015), with minor modifications described in the "Soil-Water-Balance Models" section.

\section{Flow-Duration Curve Statistics}

The FDC statistics were calculated to predict streamflow at selected exceedance-probability quantiles. The two drainage basins, the Cannon River and the St. Louis River, were subdivided into 152 nested drainage basins in the Cannon River above the Welch, Minn., streamgage, and 353 nested drainage basins in the St. Louis River above the Scanlon, Minn., streamgage. The selected exceedance-probability quantiles $(0.95,0.90,0.50$, and 0.02$)$ were used as a representation of the spatial streamflow contribution from different parts of the drainage basins. The 13 exceedance probabilities were developed in Ziegeweid and others (2015) using the weighted left-censored regression method (Helsel and Hirsch, 2002). Regional regression equations were developed for five hydrologic regions in Minnesota; the Cannon and St. Louis drainage basins contain three of the five regions, including region $\mathrm{BC}$ that combines regions B and C (Lorenz and others, 2010). An illustration of the regional boundaries, regions $\mathrm{D}$ and $\mathrm{E}$ were present in the Cannon River and region $\mathrm{BC}$ was present in the St. Louis River, is shown in figure 4.

The regional regression equations for the flow-duration curves rely upon explanatory variables related to basin characteristics. The regional regression equations used in this study are based on five basin characteristics (Ziegeweid and others, 2015): (1) drainage area, in square miles (DRNAREA); (2) percentage of drainage basin area consisting of lakes and wetlands (STORAGE); (3) percentage of drainage basin area consisting of hydrologic soil group C (SOILC); (4) percentage of mean basin low-lying flatland (PFLATLOW); and (5) percentage of area of forested land (FOREST). The FDC statistics for the 505 nested drainage basins were calculated from the imported explanatory basin characteristics using the estFDC method from the R package DVstats (Lorenz, 2016). Once the 13 exceedance-probability quantiles that define the FDC were calculated for each of the 505 nested drainage basins, these quantiles were exported from R into Microsoft ${ }^{\circledR}$ Excel for further postprocessing; all the FDC statistics are available on USGS ScienceBase (Smith, 2017a, 2017b). 


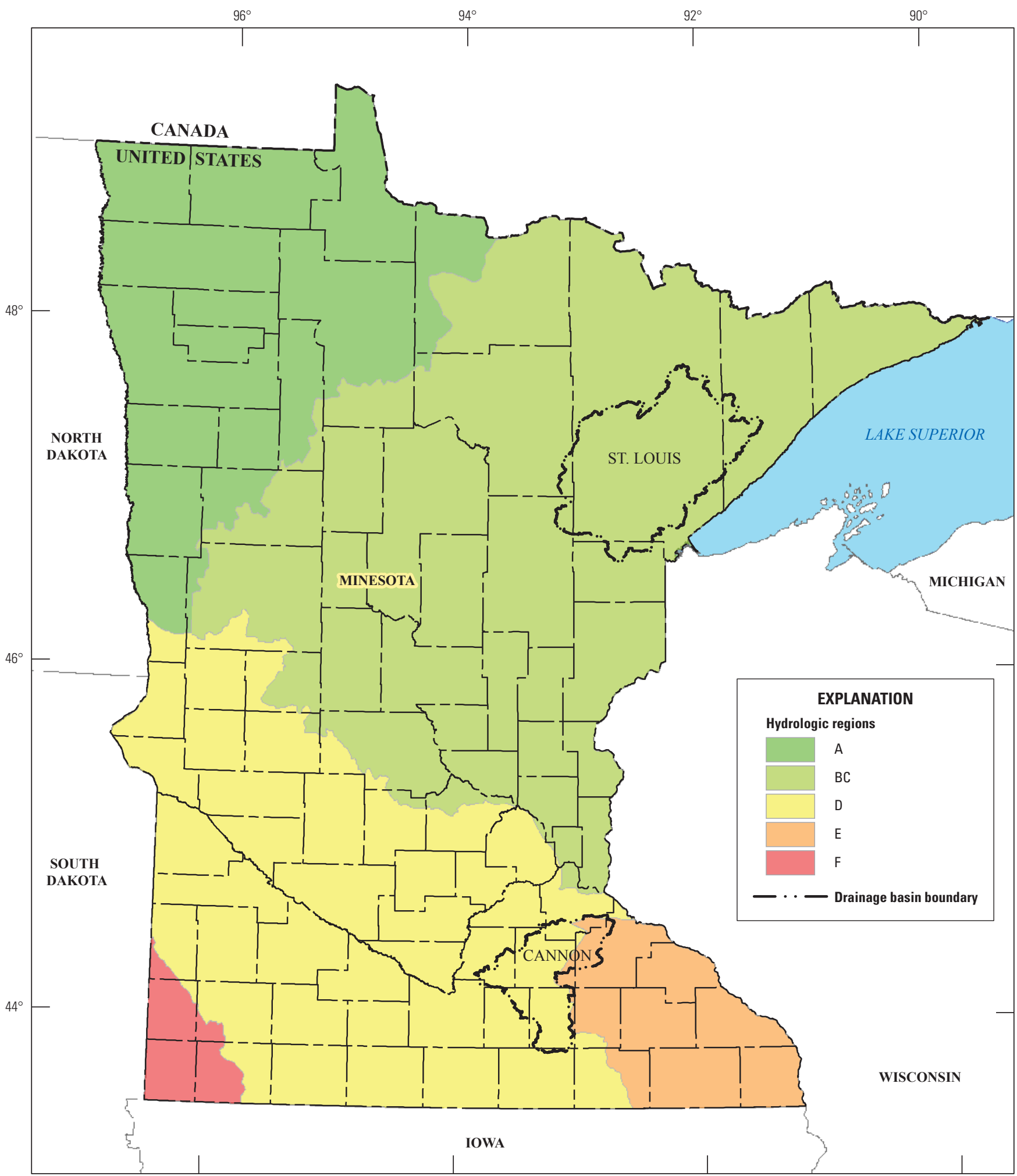

Base map modified from U.S. Geological Survey, Minnesota Department of Natural Resources and other digital data, various scales

Univeral Transverse Mercator projection, zone 15 North

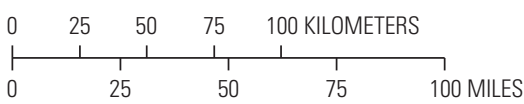

North American Datum of 1983

Figure 4. The five hydrologic regions in Minnesota, as defined by the regional regression equations from Ziegeweid and others (2015), along with the Cannon River drainage basin (above the Cannon River at Welch, Minnesota [U.S. Geological Survey station number 05355200]), and the St. Louis River drainage basin (above the St. Louis River at Scanlon, Minnesota [U.S. Geological Survey station number 04024000]). 


\section{Soil-Water-Balance Models}

The SWB model uses a modified Thornthwaite-Mather SWB accounting method (Thornthwaite and Mather, 1955, 1957) to estimate potential recharge to groundwater and surface runoff on a daily basis (Westenbroek and others, 2010). The SWB approach calculates the values of the water-budget components based on relations among surface runoff, land cover, hydrologic soil group, maximum soil-water capacity, ET estimates, and temperature. Each of the water-budget components is handled by one or more modules within the SWB model. Within the SWB approach, potential recharge is calculated within each grid cell of the model domain separately based on the differences among sources (precipitation, snowmelt, inflow), sinks (interception, outflow, ET), and changes in soil moisture ( $\Delta$ soil moisture). Outflow from each grid cell, also known as surface runoff, is calculated by the U.S. Department of Agriculture Natural Resources Conservation Service curve number rainfall-runoff relation, also known as the curve number method (Cronshey and others, 1986).

The SWB model uses the soil and land-cover lookup table to assign model cell properties related to soils and land cover (Westenbroek and others, 2010). The soil and land-cover lookup table cross-references the 15 land-cover classes in Minnesota, as derived from the National Land Cover Database (NLCD) classification (Homer and others, 2007; Fry and others, 2011) to five soil classes (four hydrologic soil group classes plus a special organic soil class) to assign the curve number, daily maximum recharge (in inches per day), and the root-zone depth (in feet). Hydrologic soil group data used in the SWB model were obtained from two separate soil geographic databases, both distributed by and available for download from the U.S. Department of Agriculture Natural Resources Conservation Service (Natural Resources Conservation Service, 2014): (1) the Soil Survey Geographic (SSURGO) database and (2) the State Soil Geographic (STATSGO) database.

Individual SWB models were used as a method for estimating potential recharge and surface runoff for the Cannon River and St. Louis River drainage basins. The SWB models calibrated for this study were largely based on the Smith and Westenbroek (2015) SWB model, which estimated the average potential groundwater recharge across Minnesota from 1996 through 2010 at a 1-km² resolution. Further calibration simulations for this study compared the potential recharge estimate from the SWB model to annual base-flow estimates derived from hydrograph separation techniques using the USGS groundwater toolbox (Barlow and others, 2015). Additionally, the sum of annual potential recharge and runoff from the individual SWB models was compared to the annual mean flow for the two drainage basins at the previously mentioned streamgages.
For this report, the published statewide SWB model (Smith and Westenbroek, 2015) was rerun for the period 1996-2010 (Smith, 2017a, 2017b). All meteorological data were provided by the Daymet dataset, which provided key climatological data such as daily precipitation, minimum daily temperature, and maximum daily temperature (Thornton and others, 1997). The grid was refined to a 100 -square meter resolution, rather than the original $1-\mathrm{km}^{2}$ resolution, including the other inputs such as the hydrologic soil groups and available soil-water capacity. The soil and land-cover lookup table from the published statewide SWB model (Smith and Westenbroek, 2015) was used for the Cannon and St. Louis River drainage basin SWB models with only slight adjustments as explained in the next two sections. One feature of the soil and land-cover lookup table of the statewide model, interception, was zeroed out for all values; interception for SWB was defined as the part of precipitation intercepted by the plant canopy and lost to ET but was a minimal component of the statewide model and technically has overlap with curve numbers.

\section{Cannon River Drainage Basin}

Further refinement of the Cannon River SWB model (Smith, 2017a) consisted of manual calibrations comparing the potential recharge estimates to the annual base-flow estimates from the Cannon River at Welch, Minn., streamgage (USGS station number 05355200). The annual base-flow estimates were generated using three different hydrograph separation techniques: PART (Rutledge, 1998), HYSEP fixed-interval method (Sloto and Crouse, 1996), and HYSEP sliding method (Sloto and Crouse, 1996). Additionally, the combined potential recharge and surface runoff estimates were compared to annual mean streamflow from the same streamgage. As a baseline SWB model, the published statewide SWB model with the increased 100-m resolution was used, and manual adjustments were completed only on the soil and land-cover lookup table. The construction of the original model was preserved as much as possible; only multiplier adjustments were made to parts of the lookup table.

For an individual iteration, subgroups of curve numbers and root-zone depths within the lookup table were altered by a multiplier to determine if the new set of parameter values improved the difference between the SWB model results and both the base-flow estimates (from the hydrograph separation techniques) and total flow. Improvements in the SWB model calibration from the statewide model were evaluated using relative errors. The relative error between the 15-year mean annual potential recharge estimates from SWB and the 15-year mean annual base flow estimates from the three different hydrograph separation techniques was considered with little emphasis on individual years. The relative error 
(dimensionless) of the potential recharge estimate from the SWB model for each drainage basin in table 2 was calculated by using equation 1 :

relative error $=\frac{\text { potential recharge }-(\text { mean base }- \text { flow estimate })}{\text { mean base }- \text { flow estimate }}$

where the potential recharge, in inches per year, is obtained from the SWB model and the mean base-flow estimate is the mean of the three base-flow estimates determined using hydrograph separation techniques, in inches per year.

After several iterations, the final calibration yielded relative errors for the overall mean base-flow estimate and total flow estimate of less than $(<) 0.01 \mathrm{ft}^{3} / \mathrm{s}$; for the individual years,

Table 2. Annual mean base flow estimates rates (from 1996 to 2010) using three hydrograph separation techniques for the Cannon River at Welch, Minnesota (U.S. Geological Survey station number 05355200), used in model calibration analysis in comparison to the Soil-Water-Balance model estimated annual potential recharge rates. Additional comparison shown between the annual mean streamflow and the Soil-Water-Balance model estimated annual sum of potential recharge and surface runoff rates.

[in/yr, inch per year; <, less than]

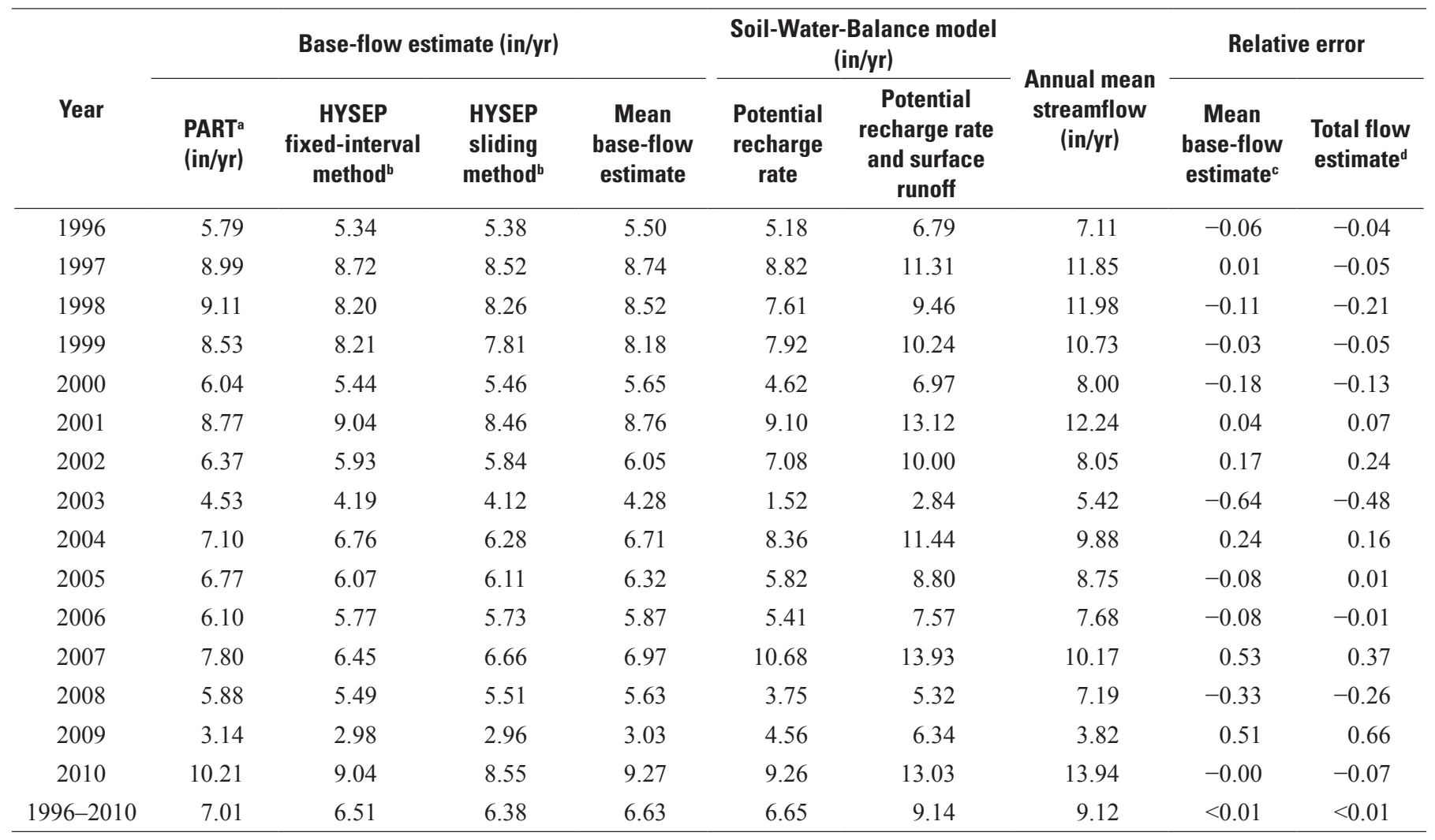

aRutledge (1998).

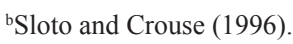

${ }^{\mathrm{c}}$ The relative error is the soil-water-balance potential recharge estimate to the mean of the three different base-flow estimates (equation 1).

${ }^{\mathrm{d}}$ The relative error is the soil-water-balance estimate (potential recharge and surface runoff) to the annual mean streamflow (equation 1). 
the mean base-flow estimate relative errors ranged from -0.64 to $0.53 \mathrm{ft}^{3} / \mathrm{s}$, and the total flow estimate ranged from -0.48 to $0.66 \mathrm{ft}^{3} / \mathrm{s}$ (table 2). Compared to the original Minnesota statewide SWB model, the following differences were made for the Cannon River for the soil and land-cover lookup table: (1) all curve numbers for the NLCD land-use classifications (LUCs) of grassland/herbaceous (LUC 71), pasture/hay (LUC 81), and cultivated crops (LUC 82) were multiplied by 1.08; and (2) all root-zone depths for the NLCD LUCs of grassland/herbaceous (LUC 71), pasture/hay (LUC 81), and cultivated crops (LUC 82 ) were multiplied by 0.82 . Besides these changes and the zeroing out of the interception values mentioned earlier, all other features of the Cannon River SWB model (Smith, 2017a) were identical to the published Minnesota statewide SWB model (Smith and Westenbroek, 2015).

\section{St. Louis River Drainage Basin}

Similar to the Cannon River SWB model, further refinement of the St. Louis River SWB model (Smith, 2017b) consisted of manual calibrations comparing the potential recharge estimates to the annual base-flow estimates from the St. Louis River at Scanlon, Minn. (USGS station number 04024000). The same annual base-flow estimates were generated, and the combined potential recharge and surface runoff estimates were compared to annual mean streamflow from the Scanlon streamgage. The baseline St. Louis River SWB model was run with the published statewide SWB model using an increased 100-m resolution, and manual adjustments were completed only on the soil and land-cover lookup table and the SWB control file.

For an individual iteration, subgroups of curve numbers and root-zone depths within the lookup table, in addition to the rainfall and snowfall multipliers from the control file, were altered to determine improvements in the fit between the same calibration criteria outlined for the Cannon River SWB model. Model calibration improvements were evaluated using relative errors.

After several iterations, the final calibration yielded relative errors for the overall mean base flow estimate and total flow estimate of $<0.01 \mathrm{ft}^{3} / \mathrm{s}$; for the individual years, the mean base flow estimate relative errors ranged from -0.53 to 0.70 $\mathrm{ft}^{3} / \mathrm{s}$, and the total flow estimate ranged from -0.21 to $0.63 \mathrm{ft}^{3} / \mathrm{s}$ (table 3). Compared to the original Minnesota statewide SWB model, the following differences were made for the St. Louis River in the soil and land-cover lookup table: (1) all curve numbers for the NLCD LUCs of deciduous forest (LUC 41), evergreen forest (LUC 42), and mixed forest (LUC 43) were multiplied by 1.25; and (2) all curve numbers for the NLCD LUCs of woody wetlands (LUC 90) and emergent herbaceous wetlands (LUC 95) were increased from 60 to 83. Within the SWB control file, the rainfall and snowfall correction factors were increased from 1.00 to 1.092 . In addition to the zeroing out of the interception values, all other features of the St. Louis River SWB model (Smith, 2017b) were identical to the published Minnesota statewide SWB model (Smith and Westenbroek, 2015).

\section{Adjusting the Flow-Duration Curve Statistics using the Soil-Water-Balance Model Output}

The SWB components of potential recharge and outflow were used as surrogates for base flow and surface runoff, respectively; therefore, the sum of the 15-year means for these two SWB water budget components was used to calculate the long-term mean total flow from the SWB model. In ArcGIS 10.4 (Esri, 2017), the mean SWB flow for each of the 505 drainage basins was calculated and exported to Microsoft ${ }^{\circledR}$ Excel. The 13 exceedance-probability quantiles that define the FDC, previously calculated for each of the 505 drainage basins, were further processed to determine the mean FDC flow (Smith, 2017a, 2017b).

The mean FDC flow is defined as the area underneath the FDC curve. The mean FDC flow was calculated by multiplying each flow percentile by the respective FDC statistic. Each flow percentile was assumed to represent the flow at the halfway point between the surrounding percentiles (or 0 or 100 in the two end-members); for example, in the 13 FDC statistics for this study, the 5 th percentile $(0.05)$ represents the mean flow value for 0.035 to 0.075 percent, the 10 th percentile $(0.10)$ represents the mean flow value for 0.075 to 0.175 percent, and so forth. So, if the FDC exceedance probability for the 5 th percentile was $1,000 \mathrm{ft}^{3} / \mathrm{s}, 1,000 \mathrm{ft}^{3} / \mathrm{s}$ would be multiplied by 0.04 (difference between 0.035 and 0.075 ); if the FDC exceedance probability for the 10th percentile was $750 \mathrm{ft}^{3} / \mathrm{s}, 750 \mathrm{ft}^{3} / \mathrm{s}$ would be multiplied by 0.10 (the difference between 0.075 and 0.175). These calculations for all 13 FDC exceedance probabilities would be carried out and summed to calculate the mean FDC flow. This calculation was completed for all 505 drainage basins.

The next step was to calculate the ratio of mean SWB total flow to mean FDC flow. The ratios differed for each nested drainage basin and ranged from 0.075 to 1.757 . The ratio was multiplied by the previously calculated FDC exceedance probabilities, thereby defining an adjusted set of 13 FDC exceedance probabilities. From these adjusted FDC exceedance probabilities, a subset of four flow conditions was selected for the streamflow distribution maps; however, any of the 13 FDC exceedance probabilities could be mapped as a typical flow condition across the drainage basin for a given exceedance probability. The four chosen flow conditions, (1) extreme low-flow conditions, comparable to an exceedance-probability quantile of 0.95 ; (2) low-flow conditions, comparable to an exceedance-probability quantile of 0.90 ; (3) median flow, comparable to an exceedance-probability quantile of 0.50; and (4) a high-flow condition, comparable to an exceedance-probability quantile of 0.02 , were selected for illustrative purposes and were based upon feedback from Minnesota Department of Natural Resources and Minnesota Pollution Control Agency personnel (sheets 1 and 2). 
Table 3. Annual mean base flow estimates rates (from 1996 to 2010) using three hydrograph separation techniques for the St. Louis River at Scanlon, Minnesota (U.S. Geological Survey station number 04024000), used in model calibration analysis for comparison to the Soil-Water-Balance model estimated annual potential recharge rates. Additional comparison shown between the annual mean streamflow and the Soil-Water-Balance model estimated annual sum of potential recharge and surface runoff rates.

[in/yr, inch per year; <, less than]

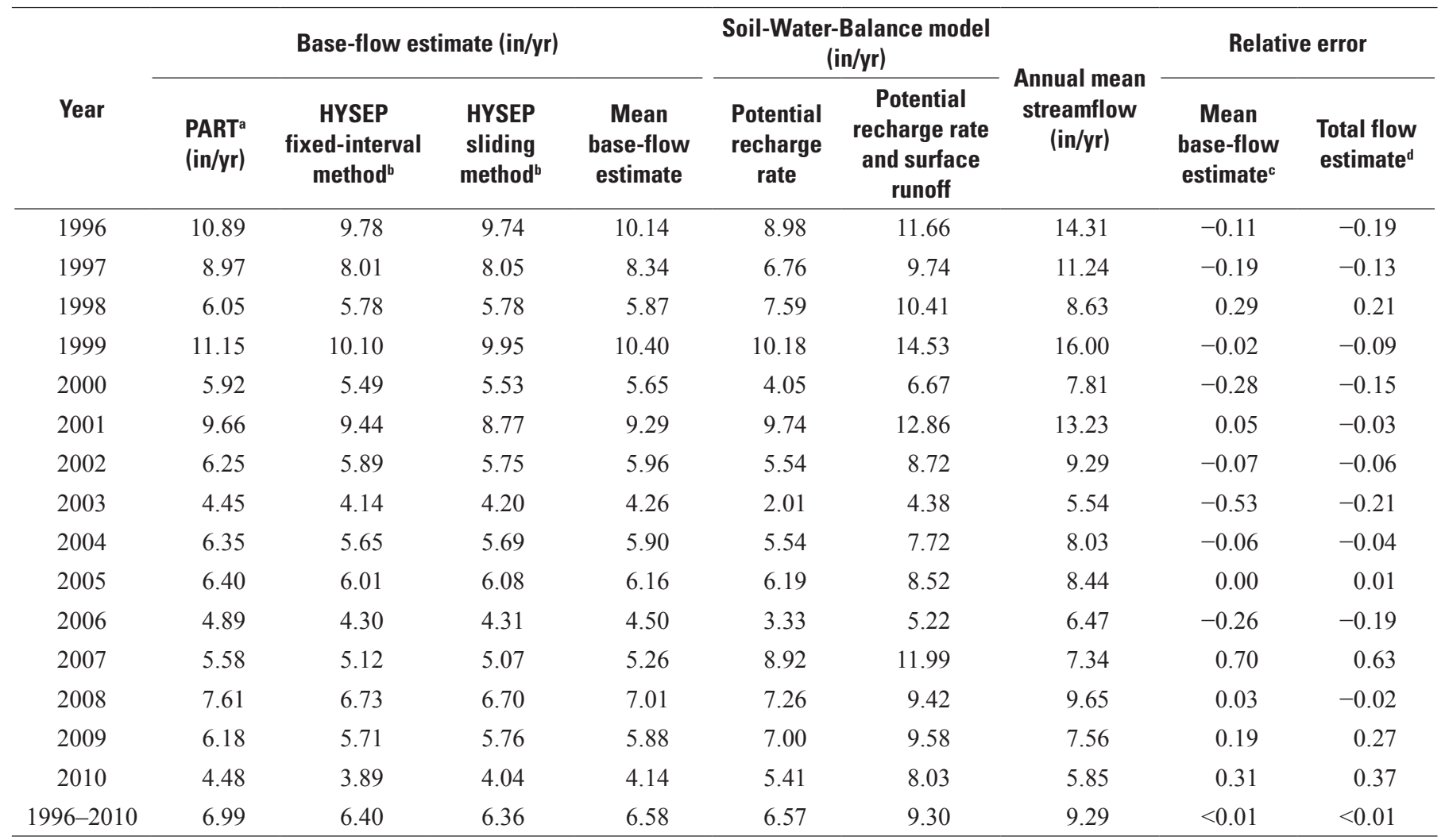

aRutledge (1998).

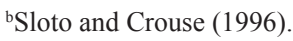

${ }^{c}$ The relative error is the soil-water-balance potential recharge estimate to the mean of the three different base-flow estimates (equation 1).

${ }^{\mathrm{d}}$ The relative error is the soil-water-balance estimate (potential recharge and surface runoff) to the annual mean streamflow (equation 1).

\section{Limitations and Assumptions}

The limitations and assumptions for the streamflow distribution maps inherently depend on the underlying FDC statistics and SWB model results. A full understanding of model limitations and assumptions is necessary to better evaluate the performance of any hydrologic model. The SWB model was originally developed to allow for recharge calculations based on readily available data and standardized parameters for short-term periods (Westenbroek and others, 2010). Both SWB models used in this study were intended to obtain estimates of the amount of potential recharge and surface runoff; however, in this study, mean potential recharge and surface runoff estimates (that is, the mean for the 15 -year period 1996-2010) were calculated for the 15-year period from 1996 to account for climate cycles and variability in surficial aquifer groundwater flow rates.
The SWB conceptual model for this study assumed that the base-flow component from the hydrograph separation technique was correct, even though this base-flow estimate was a simulated result. For comparisons made in this study, all SWB potential recharge was assumed to become base flow to the respective streamgaged drainage basin; furthermore, all groundwater exchange between the surficial aquifer and deeper aquifers was assumed to be at steady state. Finally, drainage basin boundaries of the streamgaged surface-water bodies were assumed to coincide with the boundaries of contributing recharge areas to the surficial aquifer, even though these boundaries do not always coincide (Kanivetsky, 1979).

General limitations and assumptions of the SWB model are discussed in great detail in the conceptual SWB report (Westenbroek and others, 2010) and the Minnesota statewide SWB model (Smith and Westenbroek, 2015). First, potential recharge is assumed to eventually become actual recharge. 
Next, because the path or distance to the water table is not known, the SWB model only represents water leaving the root zone. The model assumes that recharge is instantaneous within the daily time step, but actual recharge can sometimes take months or even years. Even if the recharge reaches the water table in days to weeks, it can take much longer for the same recharge water to become base flow to the nearest surface-water body. Theoretical limitations to the SWB model also relate to the aggregation of meteorological data to daily time steps; however, except for groundwater-flow models for small areas, daily time steps are considered reasonable and are recommended for water-budget tabulations (Healy and Scanlon, 2010).

Several limitations warrant consideration when using the FDC statistics presented in this report. The applicability and accuracy of the underlying regional equations depend on if the basin characteristics calculated for an ungaged stream location are within the range of the values for variables used to develop the regression equations. Inconsistencies may happen because regional regression equations were developed separately and have variable estimation intervals depending on the size and variability of the datasets used to develop regression equations (Ziegeweid and others, 2015). Additionally, adjustments to the regression equations based on the mean flow from the SWB model assumes that the bias in the regression equation estimates are constant across the FDC. Estimates at the extremes often exhibit more bias than estimates at the mean flow, so manipulation of the low-flow estimates would lead to a higher bias.

Several factors affect the estimation accuracy of the underlying regression equations to develop the FDC statistics. Estimation accuracy depends on the sample size, the accuracy of each recorded streamflow, and how well the chosen distribution fits the actual distribution of the data (Lorenz and others, 2010). The accuracies of regression estimates are affected by errors in explanatory variables, and systematic errors in the computation of the response variable can bias estimates.

Special attention must be given to censored values and the number of significant figures used. Because of the uncertainty in measuring and estimating flows less than $0.1 \mathrm{ft}^{3} / \mathrm{s}$, the censoring threshold used to develop the left-censored regression equations was set at $0.1 \mathrm{ft}^{3} / \mathrm{s}$; thus, any regression estimates that were $0.1 \mathrm{ft}^{3} / \mathrm{s}$ or less were reported as less than $0.1 \mathrm{ft}^{3} / \mathrm{s}$. Because the precision of response and explanatory variable data used to develop the equations commonly was limited to three significant figures, selected-statistic streamflows estimated from the regression equations also were limited to three significant figures. The discussion from Ziegeweid and others (2015) is recommended for a further summary of limitations and assumptions for FDC statistics.

\section{Summary}

Streamflow distribution maps for the Cannon River and St. Louis River drainage basins were developed by the U.S. Geological Survey, in cooperation with the Legislative-Citizen Commission on Minnesota Resources, to illustrate relative and cumulative streamflow distributions. The Cannon River was selected to provide baseline data to assess the effects of potential surficial sand mining, and the St. Louis River was selected to determine the effects of ongoing Mesabi Iron Range mining. These maps (available at https://doi.org/10.3133/sim3390) can help guide potential State cooperators such as the Minnesota Department of Natural Resources and the Minnesota Pollution Control Agency for proactive water management, ensure streamflows meet ecological needs at different flow conditions, and assist with decisions for groundwater appropriations at low-flow conditions.

These maps were developed using flow-duration curve (FDC) statistics in conjunction with Soil-Water-Balance (SWB) model output, specifically potential recharge and surface runoff. The mean flow calculated from the FDC statistics was compared to the mean total flow (potential recharge estimates and the surface runoff estimates) from the SWB models. The ratio of mean SWB total flow to mean FDC flow was calculated, and these ratios were used to readjust the 13 FDC exceedance probabilities. The selected streamflow distribution maps illustrate streamflow contributions from different parts of the drainage basin for typical conditions, not necessarily the contribution for any particular time.

A subset of the FDC exceedance probabilities defining the following flow conditions was mapped for 505 nested drainage basins (152 nested drainage basins in the Cannon River and 353 nested drainage basins in the St. Louis River): (1) extreme low-flow conditions, comparable to an exceedance-probability quantile of 0.95 ; (2) low-flow conditions, comparable to an exceedance-probability quantile of 0.90 ; (3) a median condition, comparable to an exceedance-probability quantile of 0.50 ; and (4) a high-flow condition, comparable to an exceedance-probability quantile of 0.02 .

\section{References Cited}

Anderson, C.R., Niemala, Scott, Anderson, Jesse, Grayson, Stacia, Monson, Bruce, Christopherson, Dave, Lundeen, Ben, Jasperson, Jeff, Kennedy, Mike, Parson, Kris, and Kelly, Mike, 2013, St. Louis River watershed monitoring and assessment report: Minnesota Pollution Control Agency document number wq-ws3-04010201b, 200 p. [Also available at https:/www.pca.state.mn.us/sites/default/files/ wq-ws3-04010201b.pdf.] 
Anderson, W.H., Jr., Farrell, D.F., Broussard, W.L., and Felsheim, P.E., 1974, Water resources of the Cannon River watershed, southeastern Minnesota: U.S. Geological Survey Hydrologic Atlas 522, 3 pls. [Also available at https://pubs.er.usgs.gov/publication/ha522.]

Barlow, P.M., Cunningham, W.L., Zhai, Tong, and Gray, Mark, 2015, U.S. Geological Survey groundwater toolbox, a graphical and mapping interface for analysis of hydrologic data (version 1.0) - User guide for estimation of base flow, runoff, and groundwater recharge from streamflow data: U.S. Geological Survey Techniques and Methods, book 3, chap. B10, 27 p. [Also available at https://doi.org/10.3133/ tm3B10.]

Bredehoeft, John, 1997, Safe yield and the water budget myth: Ground Water, v. 35, no. 6, p. 929. [Also available at https://doi.org/10.1111/j.1745-6584.1997.tb00162.x.]

Cronshey, Roger, McCuen, R.H., Miller, Norman, Rawls, Walter, Robbins, Sam, and Woodward, Don, 1986, Urban hydrology for small watersheds-TR-55 (2nd ed.): Washington, D.C., U.S. Department of Agriculture, Soil Conservation Service, Engineering Division, Technical Release 55, 164 p. [Also available at https://www.nrcs.usda.gov/ Internet/FSE_DOCUMENTS/stelprdb1044171.pdf.]

Czuba, C.R., Fallon, J.D., and Kessler, E.W., 2012, Floods of June 2012 in northeastern Minnesota: U.S. Geological Survey Scientific Investigations Report 2012-5283, 42 p. with 3 app. [Also available at https://pubs.usgs.gov/ sir/2012/5283/.]

Esri, 2017, ArcGIS 10.4 software: Esri web page, accessed May 24, 2017, at http://www.esri.com/.

Fletcher, A., and Christin, Z., 2015, The value of nature's benefits in the St. Louis River watershed: Tacoma, Wash., U.S. Environmental Protection Agency and Fond du Lac Band of Lake Superior Chippewa, joint study, 105 p. [Also available at https://www.glifwc.org/Events/Earth\%20Economics\%20 St\%20Louis\%20River\%20Project\%20Report.pdf.]

Fry, J.A., Xian, George, Jin, Suming, Dewitz, J.A., Homer, C.G., Yang, Limin, Barnes, C.A., Herold, N.D., and Wickham, J.D., 2011, Completion of the 2006 National Land Cover Database for the conterminous United States: Photogrammetric Engineering and Remote Sensing, v. 77, no. 9, p. 858-864. [Also available at https://www.mrlc.gov/ downloadfile2.php?file=September2011PERS.pdf.]

Groten, J.T., and Alexander, E.C., Jr., 2013, Karst hydrogeologic investigation of Trout Brook, Dakota County, Minnesota: University of Minnesota Water Resources Science Plan B MSc paper, 64 p. [Also available at https://conservancy.umn.edu/handle/11299/184787.]
Healy, R.W., and Scanlon, B.R., 2010, Estimating groundwater recharge: New York, N.Y., Cambridge University Press, $256 \mathrm{p}$.

Healy, R.W., Winter, T.C., LaBaugh, J.W., and Franke, O.L., 2007, Water budgets-Foundations for effective water-resources and environmental management: U.S. Geological Survey Circular 1308, 90 p. [Also available at https://pubs.usgs.gov/circ/2007/1308/.]

Helsel, D.R., and Hirsch, R.M., 2002, Statistical methods in water resources: U.S. Geological Survey Techniques of Water-Resources Investigations, book 4, chap. A3, 524 p. [Also available at https://pubs.er.usgs.gov/publication/ twri04A3/.]

Homer, C., Dewitz, J., Fry, J., Coan, M., Hossain, N., Larson, C., Herold, N., McKerrow, A., VanDriel, J.N., and Wickham, J., 2007, Completion of the 2001 National Land Cover Database for the conterminous United States: Photogrammetric Engineering and Remote Sensing, v. 73, no. 4, p. 337-341. [Also available at https://pubs.er.usgs.gov/ publication/70029996.]

Kanivetsky, Roman, 1979, Regional approach to estimating the ground-water resources of Minnesota: St. Paul, Minn., University of Minnesota, Minnesota Geological Survey, Report of Investigations 22, 24 p. [Also available at https://conservancy.umn.edu/handle/11299/60457.]

Ketner, K.B., 1979, Map showing high-purity silica sand of Middle Ordovician age in the Midwestern states: U.S. Geological Survey Miscellaneous Field Studies Map 1097, $1 \mathrm{pl}$. [Also available at https://pubs.er.usgs.gov/publication/ mf1097.]

LimnoTech, 2015, Cannon River watershed HSPF model development project: Minnesota Pollution Control Agency, One Water Program Final Report, 209 p.

Lindgren, John, Schuldt, Nancy, Borkholder, Brian, Howes, Tom, Levar, Andrew, Olson, Carlye, Tillma, Jeff, and Vogt, Darren, 2006, A study of the St. Louis River: Minnesota Department of Natural Resources, Section of Fisheries Completion Report F-29-R(P)-25, 153 p. [Also available at http://files.dnr.state.mn.us/areas/fisheries/duluth/ st_louis_river_study.pdf.]

Lindholm, G.F., Ericson, D.W., Broussard, W.L., and Hult, M.F., 1979 Water resources of the St. Louis River watershed, northeastern Minnesota: U.S. Geological Survey Hydrologic Atlas 586, 3 pls. [Also available at https://pubs.er.usgs.gov/publication/ha586.]

Lorenz, D.L., 2016, DVstats-Functions for manipulating daily values, R package version 0.3.3: GitHub, Inc., web page, accessed July 30, 2017, at https:/github.com/ USGS-R/DVstats. 
Lorenz, D.L., Sanocki, C.A., and Kocian, M.J., 2010, Techniques for estimating the magnitude and frequency of peak flows on small streams in Minnesota based on data through water year 2005: U.S. Geological Survey Scientific Investigations Report 2009-5250, 54 p. [Also available at https://pubs.usgs.gov/sir/2009/5250/pdf/sir2009-5250.pdf]

Lorenz, D.L., and Ziegeweid, J.R., 2016, Methods to estimate historical daily streamflow for ungaged stream locations in Minnesota: U.S. Geological Survey Scientific Investigations Report 2015-5181, 18 p. [Also available at https://doi.org/10.3133/sir20155181.]

Minnesota Department of Natural Resources, 2017, Groundwater provinces: Minnesota Department of Natural Resources web page, accessed July 13, 2017, at http://dnr.state.mn.us/groundwater/provinces/index.html.

Natural Resources Conservation Service, 2014, Web soil survey: U.S. Department of Agriculture, Natural Resources Conservation Service web page, accessed August 26, 2014, at https://websoilsurvey.nrcs.usda.gov/app/WebSoilSurvey. aspx.

RStudio Team, 2016, RStudio-Integrated development for R: RStudio, Inc., web page, accessed July 31, 2017, at https://www.rstudio.com/.

Ruhl, J.F., 1989, Water resources of the Fond du Lac Indian Reservation, east-central Minnesota: U.S. Geological Survey Water-Resources Investigations Report 88-4114, 42 p. [Also available at https://pubs.er.usgs.gov/publication/ wri884114.]

Runkel, A.C., Steenberg, J.R., Tipping, R.G., and Retzler, A.J., 2014, Geologic controls on groundwater and surface water flow in southeastern Minnesota and its impact on nitrate concentrations in streams: Minnesota Geological Survey Open File Report 14-02, 154 p. [Also available at https://conservancy.umn.edu/handle/11299/162612.]

Rutledge, A.T., 1998, Computer programs for describing the recession of ground-water discharge and for estimating mean ground-water recharge and discharge from streamflow records-Update: U.S. Geological Survey Water-Resources Investigations Report 98-4148, 43 p. [Also available at https://pubs.er.usgs.gov/publication/wri984148.]

Searcy, J.K., 1959, Flow-duration curves: U.S. Geological Survey Water-Supply Paper 1542-A, 33 p. [Also available at https://pubs.er.usgs.gov/publication/wsp1542A/.]

Setterholm, D.R., 2014, Geologic atlas user's guide-Using geologic maps and databases for resource management and planning: Minnesota Geological Survey Open-File Report 12-1, $24 \mathrm{p}$. [Also available at https://conservancy.umn.edu/ handle/11299/166713.]
Sloto, R.A., and Crouse, M.Y., 1996, HYSEP-A computer program for streamflow hydrograph separation and analysis: U.S. Geological Survey Water-Resources Investigations Report 96-4040, 46 p. [Also available at https://pubs.er.usgs.gov/publication/wri964040.]

Smith, E.A., 2017a, Soil-Water-Balance model data sets for the Cannon River drainage basin, southeast Minnesota, 1995-2010: U.S. Geological Survey data release, https://doi.org/10.5066/F72V2DMN.

Smith, E.A., 2017b, Soil-Water-Balance model data sets for the St. Louis River drainage basin, northeast Minnesota, 1995-2010: U.S. Geological Survey data release, https://doi.org/10.5066/F7Z60MJ0.

Smith, E.A., and Westenbroek, S.M., 2015, Potential groundwater recharge for the State of Minnesota using the SoilWater-Balance model, 1996-2010: U.S. Geological Survey Scientific Investigations Report 2015-5038, 85 p. [Also available at https://doi.org/10.3133/sir20155038.]

Tetra Tech, 2016, St. Louis, Cloquet, and Nemadji River basin models-volume 1-Hydrology and sediment model calibration: Minnesota Pollution Control Agency Final Report (February 4, 2016), 256 p.

Thornthwaite, C.W. and Mather, J.R., 1957, Instructions and tables for computing potential evapotranspiration and the water balance: Centerton, N.J., Laboratory of Climatology, Publications in Climatology, v. 10, no. 3, p. 185-311.

Thornthwaite, C.W., and Mather, J.R., 1955, The water balance: Centeron, N.J., Laboratory of Climatology, Publications in Climatology, v. 8, no. 1, p. 1-104.

Thornton, P.E., Running, S.W., and White, M.A., 1997, Generating surfaces of daily meteorological variables over large regions of complex terrain: Journal of Hydrology, v. 190, no. 3-4, p. 214-251. [Also available at https://doi.org/10.1016/S0022-1694(96)03128-9.]

Unthank, M.D., Newson, J.K., Williamson, T.N., and Nelson, H.L., 2012, Construction of estimated flow- and load-duration curves for Kentucky using the Water Availability Tool for Environmental Resources (WATER): U.S. Geological Survey Scientific Investigations Report 2012-5168, 14 p. [Also available at https://pubs.usgs.gov/sir/2012/5168/.]

U.S. Geological Survey, 2017, National Water Information System-Web interface: accessed July 13, 2017, at https://doi.org/10.5066/F7P55KJN.

Westenbroek, S.M., Kelson, V.A., Dripps, W.R., Hunt, R.J., and Bradbury, K.R., 2010, SWB-A modified Thornthwaite-Mather Soil-Water-Balance code for estimating groundwater recharge: U.S. Geological Survey Techniques and Methods, book 6, chap. A31, 60 p. [Also available at https://pubs.usgs.gov/tm/tm6-a31/.] 
Winter, T.C., Harvey, J.W., Franke, O.L., and Alley, W.M., 1998, Ground water and surface water-A single resource: U.S. Geological Survey Circular 1139, 79 p. [Also available at https://pubs.usgs.gov/circ/circ1139/.]

Wotzka, Paul, and Watkins, Justin, 2016, Cannon River watershed restoration and protection strategies report: Minnesota Pollution Control Agency no. wq-ws4-23a, 147 p. [Also available at https://www.pca.state.mn.us/sites/default/files/ wq-ws4-23a.pdf.]

Ziegeweid, J.R., Lorenz, D.L., Sanocki, C.A., and Czuba, C.R., 2015, Methods for estimating flow-duration curve and low-flow frequency statistics for ungaged locations on small streams in Minnesota: U.S. Geological Survey Scientific Investigations Report 2015-5170, 23 p. [Also available at https://doi.org/10.3133/sir20155170.] 
For more information about this publication, contact Director, USGS Upper Midwest Water Science Center 2280 Woodale Drive

Mounds View, MN 55112

(763) 783-3100

For additional information visit https://mn.water.usgs.gov

Publishing support provided by the

Rolla Publishing Service Center 


\section{$\frac{\mathbb{2}}{3}$}

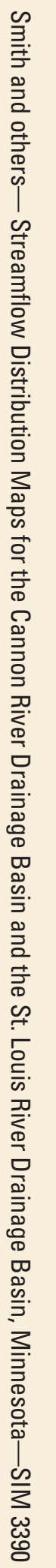

ISSN 2329-132X (online) 